\title{
LOYALITAS NASABAH PADA BANK PAPUA CABANG YOGYAKARTA
}

\author{
Nevri Bayage \\ Fakultas Ekonomi dan Bisnis, Universitas Pembangunan Nasional Veteran Yogyakarta \\ bayagenevri4@gmail.com \\ Dyah Sugandini* \\ Fakultas Ekonomi dan Bisnis, Universitas Pembangunan Nasional Veteran Yogyakarta \\ dini@upnyk.ac.id \\ Purbudi Wahyuni \\ Fakultas Ekonomi dan Bisnis, Universitas Pembangunan Nasional Veteran Yogyakarta \\ purbudi.wahyuni@upnyk.ac.id
}

\begin{abstract}
This study aims to analyze the factors that affect customer loyalty to customers of Bank Papua Branch Yogyakarta. Customer loyalty in this research is influenced by trust, switching barriers and bank image. Respondents in this study are all students who have savings in Bank Papua branch of Yogyakarta and domiciled in Yogyakarta. This research is a survey research by using questionnaires. The analytical tool used for hypothesis testing is SEM-PLS. The results of data analysis show that trust has a significant positive effect on switching barriers and image. Trust has no significant effect on loyalty. Switching barriers affect loyalty. The image is not proven to have a significant effect on loyalty.
\end{abstract}

Keyword: loyalty, trust, switching barriers and image

\section{PENDAHULUAN}

Bank adalah badan usaha yang menghimpun dana dari masyarakat dalam bentuk simpanan dan meyalurkannya pada masyarakat dalam bentuk kredit dan atau bentuk-bentuk lainnya dalam rangka meningkatkan kehiduapan rakyat banyak, seperti yang tertuang dalam Undang-Undang RI Nomor 10 Tahun 1998. Seiring dengan berkembangnya zaman, banyak berdiri lembaga atau perusahaan bahkan atas nama individu yang menjalankan bisnis jasa perbankan. Perusahaan perbankan hadir guna memenuhi kebutuhan para nasabahnya, semakin banyak bermunculan perbankan untuk bersaing guna menarik minat nasabah dalam menggunakan jasa perbankan.Bank Papua adalah salah satu cabang bank umum yang berdiri di kota Yogyakarta yang terletak di Ruko Raflesia Babarsari. Bank Papua menyediakan serangkaian produk jasa dan layanan perbankan. Antara lain Dana Pihak Ketiga (DPK) yang terdiri dari giro, tabungan, dan deposito. Ada pula kredit modal kerja, kredit karyawan, kredit kendaraan bermotor, serta tersedia jasa layanan perbankan.

Tujuan pendirian cabang Bank Papua di Yogyakarta. Bank Papua bertujuan untuk melayani masyarakat Papua yang ada di Yogyakarta dan juga memberikan kontribusi untuk pertumbuhan ekonomi di Yogyakarta. Saat ini jumlah mahasiswa Papua yang kuliah di Yogyakarta sekitar 7500, belum termasuk mereka yang sudah berkeluarga. Jika ditotal masyarakat Papua yang tinggal di Yogya mencapai lebih kurang 10.000-15.000orang. Kehadiran Bank Papua ini bisa menjadi jembatan bagi pelajar dan mahasiswa asal Papua yang sedang kuliah di Yogyakarta. Tujuan didirikan bank papua di yogyakarta selain karena kepedulian Bank Papua terhadap dunia pendidikan, juga karena komitmen dan wujud tanggung jawab sosial perusahaan. Berikut perkembangan jumlah nasabah Bank Papua Cabang Yogyakarta yang berasal dari kalangan mahasiswa dapat ditunjukkan dalam tabel berikut. 
Tabel 1

Perkembangan Nasabah Mahasiswa Papua di Bank Papua Cabang Yogyakarta Tahun 2017

\begin{tabular}{ccccc}
\hline Tahun & Tabunganku & Simpeda & Simanja & Total \\
\hline 2014 & & 280 & 280 & 560 \\
2015 & 70 & 242 & 242 & 554 \\
2016 & 142 & 176 & 163 & 481 \\
2017 & 312 & 90 & 133 & 535 \\
\hline Total & \multicolumn{4}{c}{}
\end{tabular}

Bank Papua mempunyai produk tabungan yang merupakan produk tabungan yang diperuntukan bagi perorangan yang diterbitkan secara bersama-sama oleh bankbank di Indonesia guna menumbuhkan budaya menabung serta meningkatkan kesejahteraan Perkembangan jumlah nasabah Bank Papua Cabang Yogyakarta yang berasal dari kalangan mahasiswa juga dapat ditunjukkan dalam grafik berikut ini.

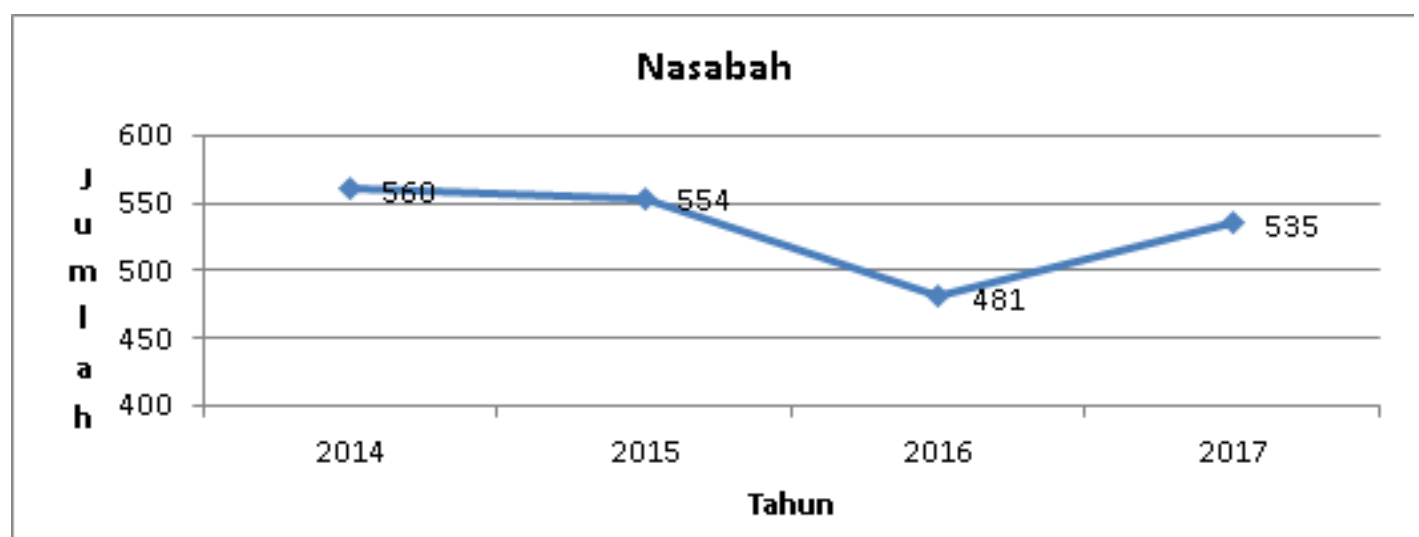

Gambar 1. Perkembangan Nasabah Bank Papua Cabang Yogyakarta Tahun 2016

Berdasarkan tabel dan grafik di atas, maka dapat dijelaskan bahwa perkembangan jumlah nasabah dari kalangan mahasiswa Papua makin menurun. Pada tahun 2014 menunjukkan jumlahnya ada 560mahasiswa, dan terlihat pada tahun-tahun selanjutnya jumlah nasabah dari kalangan mahasiswa selalu menunjukkan penurunan. Walaupun tercatat di tahun 2017 jumlah nasabah dari kalangan mahasiswa beranjak meningkat yaitu sejumlah 535 mahasiswa, hal ini menunjukkan fluktuasi nasabah Bank Papua Cabang Yogyakartadari kalangan para mahasiswa Papua yang ada di Yogyakarta. Kondisi persaingan yang semakin ketat, setiap perusahaan tetap harus mampu bertahan, bahkan harus dapat terus berkembang. Salah satu hal penting yang perlu dilakukan dan dipertahankan oleh perusahaan adalah mempertahankan pelanggan yang telah ada dan terus bersaing dalam medapatkan pelanggan-pelanggan baru. Pemasar sangat mengharapkan dapat mempertahankan pelanggannya dalam jangka panjang, bahkan jika mungkin untuk selamanya.

\section{LATAR BELAKANG}

Loyalitas konsumen menggambarkan para konsumen yang tidak hanya puas tetapi juga senang dengan produk atau jasa (Bhote, 1996). Oleh karena itu, para konsumen dengan antusias menginformasikan orang lain mengenai pengalaman mereka dengan produk dan jasa. Di samping itu, para konsumen semacam itu tidak hanya membeli kembali barang-barang atau jasa-jasa perusahaan, tetapi memperluas loyalitas mereka ke sejumlah besar barang dan jasa lainnya yang diproduksi oleh perusahaan. Memiliki konsumen yang loyal memungkinkan sebuah perusahaan untuk mengembangkan dan mempertahankan hubungan-hubungankonsumenjangkapanjang (Zeithaml dan Bitner, 1996). Sugandini (2003; Sugandini et al, 2017; Sugandini et al, 2018) 
menyebutkaan bahwa loyalitas dipengaruhi oleh citra, kualitas layanan dan kepuasan.

Subroto dan Anita (2014) menunjukkan bahwa kepercayaan citra, dan switching barriers pada perusahaan berpengaruh langsung terhadap loyalitas konsumen. Ishak dan Luthfi (2011) menunjukkan bahwa loyalitas konsumen terhadap layanan tertentu tidak hanya ditentukan oleh kualitas layanan saja tetapi juga ditentukan oleh kemungkinan adanya hambatan untuk berpindah ke layanan lain (switching barriers). Tingkir (2014) menyebutkan bahwa citra mempengaruhi loyalitas kepada merek. (Rahadian, 2006). Rahadian (2006) menyatkan switching barriers pada perusahaan tinggi, mereka dapat terus mempertahankan pelanggan meski tingkat kepuasan pelanggan rendah. Semakin meningkatnya tuntutan-tuntutan konsumen juga menimbulkan tantangan bagi pengembangan loyalitas konsumen dalam industri jasa (Kirwin, 1992). Para konsumen dewasa ini menuntut produk-produk dan jasa berkualitas tinggi dan kurang menerima produk-produk dan jasa-jasa dengan kualitas menengah. Dalam industri perhotelan, situasi ini semakin mencolok dengan tingginya persaingan dalam suatu industri matang. Untuk itu, para manajer hotel harus mengembangkan strategi-strategi kreatif untuk menjamin bahwa dua kategori konsumen, yakni konsumen yang ada saat ini dan yang baru, menjadi loyal.

\section{TUJUAN PENELITIAN}

Tujuan penelitian ini adalah untuk menganalisisfaktor-faktoryangmempengaruhi loyalitas nasabah yang dipengaruhi oleh kepercayaan, switching barriers dan citra bank pada nasabah Bank Papua Cabang Yogyakarta.

\section{MANFAAT PENELITIAN}

Penelitian ini memberi kontribusi pada studi-studi terdahulu mengenai loyalitas dalam beberapa aspek. Pertama, studiinimengusulkan suatu model loyalitas konsumen yang mencakup tiga anteseden, yaitu: kepercayaan, switching barriers dan citra bank . Penelitian ini diharapkan akan memberikan pemahaman yang lebih baik tentang loyalitas konsumen. Kedua, tidak seperti penelitian yang ada mengenai loyalitas konsumen, penelitian ini memusatkan perhatian pada suatu industri jasa dan bukan pada suatu industri barang-barang yang nyata. Dengan meneliti loyalitas dalam suatu konteks jasa, penelitian ini akan dapat memperluas pengetahuan tentang loyalitas konsumen dalam industri jasa. Selain itu, hasilhasil penelitian ini terbukti sangat bermanfaat bagi aplikasi praktis dalam industri perbankan khususnya Bank Papua. Studi ini membantu manajer Bank Papua dalam mengidentifikasi pelayanan maupun kinerja Bank yang bisa digunakan untuk mengembangkan loyalitas nasabah. Mengenali dan memahami aspekaspek ini bisa membantu para manajer untuk mengelola aspek-aspek yang ada di perbankan ini secara lebih efektif. Hal ini penting karena menangani loyalitas konsumen ternyata sulit ketika sulit diketahui pada aspek-aspek mana para tamu mendasari penilaian mereka tentang pengalaman bertransaksi di sebuah bank.

\section{TINJAUAN LITERATUR}

\section{Loyalitas}

Glemler dan Brown (1997), mendefinisikan loyalitas konsumen sebagai berikut: "Service loyalty is the degree to which a customer exhibits repeat purchasing behavior from received provider, processes a positive attitudinal disposition toward the provider, considers using only this provider when a neen for this service arises". Definisi ini secara jelas menunjukkan bahwa konsumen yang setia tidak hanya akan membeli ulang tetapi juga mempunyai sikap yang positif terhadap penyedia jasa misalnya, dengan merekomendasi orang lain untuk membeli (positive word-of mouth). Sebaliknya Kandampully (1998), mendefinisikan loyalitas konsumen dengan mengacu pada sikap yang diberikan oleh penyedia jasa untuk mendapatkan loyalitas konsumen dengan memberikan definisi loyalitas sebagai berikut: "A demonstration of the organization's commitment maintain the service promise". Meskipun definisi-definisi tersebut berbeda, tetapi semua mengacu loyalitas sebagai suatu hubungan jangka panjang yang positif antara penyedia jasa dengan konsumennya. Seorang yang setia terhadap penyedia jasa adalah seseorang yang selalu membeli dari penyedia jasa, mempertimbangkan penyedia tersebut 
jika membutuhkan suatu jasa di masa depan, dan mempunyai sikap yang baik terhadap penyedia jasa tersebut dengan merekomendasi teman atau kenalannya untuk melakukan transakasi bisnis dengan penyedia yang dia senangi (loyal).

\section{Kepercayaan}

Kepercayaan didefinisikan sebagai tingkat integritas, kejujuran dan kompetensi yang dipersepsikan oleh seseorang kepada orang lain lain, atau merupakan fungsi keandalan dan integritas yang dirasakan konsumen atas merek dari penyedia layanan (Morgan dan Hunt, 1994). Berry (1995) menunjukkan bahwa kepercayaan adalah factor paling penting dalam pemasaran hubungan, dan pemasaran jasa. Berry and Parasuraman (1991), menyatakan bahwa transaksi perbankan sering berhadapan dengan berisiko dan sering dikaitkan dengan produk yang tidak mempunyai informasi lengkap. Oleh karena itu, kepercayaan diperlukan untuk mengurangi risiko dan ketidakpastian yang diasosiasikan dengan transaksi layanan perbankan. Seorang nasabah yang merasa bank mereka lebih bisa dipercaya cenderung melihat risiko yang lebih besar jika harus beralih ke penyedia perbankan lainnya, sehingga nasabah ini cenderung untuk meningkatkan kesetiaan mereka.

\section{Switching barrier}

Switching barrier didefinisikan sebagai kesulitan untuk berpindah ke penyedia produk atau jasa lain yang dirasakan oleh konsumen yang tidak puas dengan layanan yang ada saat ini, atau beban keuangan, beban sosial dan beban psikologis yang dirasakan pelanggan ketika beralihke penyedia produk atau jasa lain, dengan kata lain, switching barrier memaksa para konsumen untuk tetap menggunakan produk atau jasa perusahaannya saat ini Berry (1995). Hambatan berpindah adalah rintangan yang dirasakan oleh seseorang konsumen untuk beralih dari produk lama ke produk baru. Hambatan pindah mengacu pada tingkat kesulitan untuk berpindah ke penyedia jasa lain ketika pelanggan tidak puas dengan jasa yang diterima. Hambatan pindah dapat berbentuk kendala finansial, sosial, dan psikologis yang dirasakan seorang pelanggan ketika berpindah kepenyediajasa baru. Semakin tinggi hambatan pindah, akan semakin mendorong pelanggan untuk bertahan dengan penyedia jasa lama (Setiawan dan Ukudi, 2011).Menurut Jones (2000), switching barrier adalah faktor-faktor yang menjadi penghambat untuk berpindah pada penyedia jasa lainnya

\section{Citra}

Ditcher (1995) mendefinisikan citra sebagai what citra is, and is not: "It (image) describe not individual traits or qualities, but the total impression an entity makes on the minds of others ...... an citra is not anchored in just objective data and details. It is the configuration of the whole field of the object" . Sementara itu, Normann (1995), mendefinisikan citra sebagai: "Image is a model, signifying our beliefs and our understanding of a phenomenon or situation". Robert (1993), mendefinisikan citra sebagai: "The general idea or perception that the public have of a company, unit or product". Dengan demikian citra bisa diintepretasikan sebagai persepsi atas fenomena; kesan yang tertanan dalam memori. Sehingga sebagai konsekuensinya, citra bisa melekat pada organisasi, produk atau merek.

\section{HIPOTESIS.}

Kepercayaan umumnya dilihat sebagai elemen penting dalam pengembangan komitmen pelanggan dan loyalitas (Ranaweera dan Prabhu, 2003 ). Henning-Thurau et al., (2002) berpendapat bahwa kepercayaan berpengaruh pada loyalitas. Nasabah yang memiliki kepercayaan yang tinggi pada bank tidak mudah berpindah ke bank lain dan akan tetap loyal pada bank yang bersangkutan (Ranaweera dan Prabhu, 2003). Dampak citra pada konsumen dapat dilihat sebagai berikut: Citra dapat mengkomunikasikan harapan, bersama-sama dengan program pemasaran eksternal seperti periklanan, personnal selling dan word-of-mouth communication (Gronroos, 1983).

Citra, harga, evidence of price dan service encounter merupakan seluruh faktor yang mempengaruhi persepsi konsumen terhadap service. Citra mempengaruhi persepsi konsumen karena fungsinya sebagai filter dari kegiatan operasional perusahaan (Zeithaml dan Bitner, 1996; Gronroos, 1983; Fredericks dan Salter II, 1995). Dengan demikian citra 
dapat mendukung atau tidak menentukan persepsi konsumen terhadap nilai, kualitas, kepuasan dan loyalitas (Zeithaml dan Bitner, 1996; Sobol et al., 1992; Fredericks dan Salter II, 1995).

Hipotesis yang diajukan adalah sebagai berikuit:

H1: Kepercayaan berpengaruh positif signifikan terhadap switching barriers

$\mathrm{H} 2$ : Kepercayaan berpengaruh positif signifikan terhadap citra bank

H3: Kepercayaan berpengaruh positif signifikan terhadap loyalitas nasabah

H4: Switching barriers berpengaruh positif signifikan terhadap loyalitas nasabah

H5: Citra bank berpengaruh positif signifikan terhadap loyalitas nasabah

\section{METODE PENELITIAN}

Populasi dalam penelitian ini adalah seluruh mahasiswa Papua yang menjadi nasabah di Bank Papua Cabang Yogyakarta dari tahun 2014-2017 dan menggunakan produk layanan TabunganKu yang berjumlah 524 orang. Pemilihan pada nasabah TabunganKu ini dikarenakan jumlah nasabah pada produk layanan ini yang paling besar dan pertumbuhannya pun dari tahun ke tahun selalu meningkatJumlah sampel yang diambil dalam penelitian sebanyak 84 responden.Teknik sampling yang digunakan adalah purposive sampling. Kriteria responden dalam penelitian ini adalah : mahasiswa Papua yang menjadi nasabah Bank Papua Cabang Yogyakarta, nasabah yang menggunakan produk layanan TabunganKu, dan sudah menjadi nasabah Bank Papua Cabang Yogyakarta minimal 1 tahun. Sumber data dalam penelitian ini adalah data primer. Teknik pengumpulan data yang digunakan adalah kuisioner. Analisis data penelitian menggunakan Structural Equation Model (SEM) dengan menggunakan bantuan software PLS (Partial Least Square).

\section{HASIL PENELITIAN DAN PEMBAHASAN}

\section{Karakteristik Responden}

Karakteristik responden penelitian dapat dilihat dalam tabel 2. Sebagian besar responden adalah laki-laki, usia 17-20 tahun, dengan lama pelayanan antara 1-2 hari da lama menjadi nasabah 1-3 tahun.

Tabel 2. Karakteristik Responden

\begin{tabular}{llcc}
\hline \multicolumn{1}{c}{ Karakteristik Responden } & \multicolumn{1}{c}{ Kategori } & Frekuensi & Persentase \\
\hline \multirow{2}{*}{ Jenis Kelamin } & Laki-laki & 71 & 84,5 \\
\multirow{2}{*}{ Usia } & Perempuan & 13 & 15,5 \\
& $17-20$ tahun & 35 & 41,7 \\
& $21-24$ tahun & 32 & 38,1 \\
& 25-29 tahun & 17 & 20,2 \\
& $1-2$ hari & 73 & 86,9 \\
Lama pelayanan & $3-4$ hari & 7 & 8,3 \\
& $>4$ hari & 4 & 4,8 \\
\multirow{2}{*}{ Lama menjadi nasabah } & $\leq 1$ tahun & 10 & 11,9 \\
& $>1-3$ tahun & 41 & 48,8 \\
& $>3$ tahun & 33 & 39,3 \\
\hline
\end{tabular}

\section{Deskripsi Variabel Penelitian}

Hasil wawancara dengan responden diperolah nilai rata-rata jawaban responden atas masing-masing variabel adalah sebagai berikut: 
Tabel 3. Distribusi Penilaian Tentang Kepercayaan

\begin{tabular}{cccc}
\hline No & Variable & Rerata & Keterangan \\
\hline 1 & Kepercayaan & 3,84 & Tinggi \\
2 & Switching barriers & 3,56 & Tinggi \\
3 & Citra & 3,83 & Tinggi \\
4 & Loyalitas nasabah & 3,57 & Tinggi \\
\hline
\end{tabular}

\section{Pengujian Model Penelitian}

Alat untuk menguji hipotesis dalam penelitian ini menggunakan metode Partial Least Square (PLS). PLS adalah metode alternatif analisis dengan Structural Equation Modelling (SEM) yang berbasis variance dengan keunggulan tidak memerlukan banyak asumsi Alat bantu yang dipergunakan untuk mengestimasi model adalah Smart PLS versi 2.

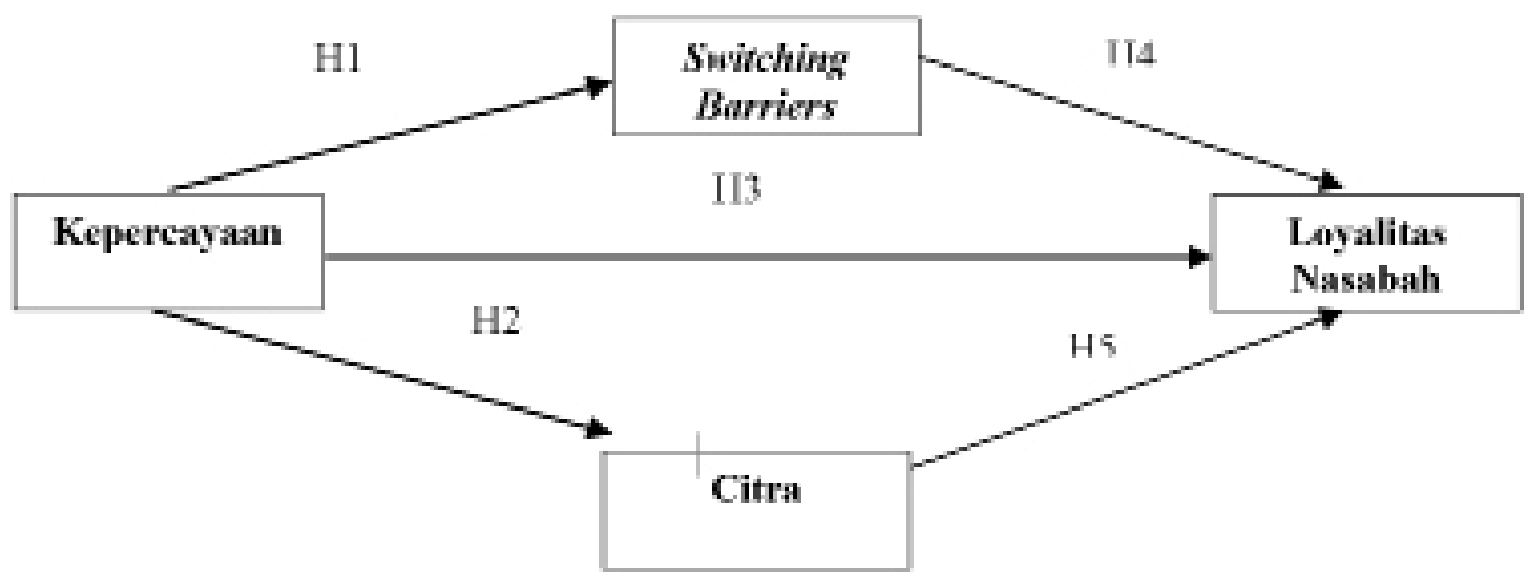

Gambar 2: Model Penelitian

5. Uji Validitas dan Reliabilitas Variabel Laten

Pada pengujian ini digunakan untuk menilai outer model yang meliputi convergent validity diukur dari nilai outer loading, discriminant validity diukur dengan nilai $A V E$, dan composite reliability atau CR untuk mengukur tingkat reliabilitas. Convergent

\section{Model Penelitian}

Model penelitian ini digambarkan dalam gambar 2, yang menunjukkan bahwa kepercayaan berpengauh pada switching barrier, swisthing barrier berpengaruh pada loyalitas nasabah. Selanjutnya kepercayaan berpengaruh pada loyalitas nasabah, kepercayaan berpengaruh pada citra, dan citra berpengaruh pada loyalitas nasabah.

Hasil Uji Convergent Validity - Outer Loading

\begin{tabular}{ccccc}
\hline Variabel & Item & Nilai Loading & Kriteria & Keterangan \\
\hline \multirow{5}{*}{ Kepercayaan } & KEP1 & 0,890997 & 0,5 & Valid \\
& KEP2 & 0,753919 & 0,5 & Valid \\
& KEP3 & 0,771493 & 0,5 & Valid \\
& KEP4 & 0,718189 & 0,5 & Valid \\
& KEP5 & 0,730921 & 0,5 & Valid \\
\hline
\end{tabular}




\begin{tabular}{ccccc}
\hline \multirow{2}{*}{ Variabel } & Item & Nilai Loading & Kriteria & Keterangan \\
\hline \multirow{3}{*}{ Switching barriers } & SB1 & 0,826731 & 0,5 & Valid \\
& SB2 & 0,899608 & 0,5 & Valid \\
& SB3 & 0,841174 & 0,5 & Valid \\
& CIT1 & 0,834574 & 0,5 & Valid \\
& CIT2 & 0,812719 & 0,5 & Valid \\
Citra & CIT3 & 0,783141 & 0,5 & Valid \\
& CIT4 & 0,771392 & 0,5 & Valid \\
& CIT5 & 0,671303 & 0,5 & Valid \\
& CIT6 & 0,645579 & 0,5 & Valid \\
& CIT7 & 0,687133 & 0,5 & Valid \\
& CIT8 & 0,748273 & 0,5 & Valid \\
& LOY1 & 0,876164 & 0,5 & Valid \\
& LOY2 & 0,844948 & 0,5 & Valid \\
& LOY3 & 0,648510 & 0,5 & Valid \\
& LOY4 & 0,862164 & 0,5 & Valid \\
\hline
\end{tabular}

Berdasarkan nilai faktor loading diatas, maka dapat disimpulkan bahwa pada tahap pengujian ini semua item dari variabel penelitian sudah valid dan telah memenuhi convergent validity atau dinyatakan valid dikarenakan seluruh item memiliki nilai loading di atas 0,5. Dari pengujian ini dapat disimpulkan bahwa pada tahap pengujian ini semua item dari variabel penelitian valid. Discriminant validity dilakukan untuk memastikan bahwa setiap konsep dari masing variabellaten berbeda dengan variabel lainnya. Model mempunyai discriminant validityyang baik jika nilai avarge variance extracted (AVE) dengan nilai $(\geq 0,5)$. Hasil pengujian discriminant validity dengannilai AVE berikut ini.

Tabel. 5

Hasil Uji Discriminant Validity - Nilai $A V E$

\begin{tabular}{|l|c|c|c|}
\hline \multicolumn{1}{|c|}{ Variabel } & AVE & Kriteria & Keterangan \\
\hline Kepercayaan & 0,601502 & 0,5 & Valid \\
\hline Switching Barriers & 0,733451 & 0,5 & Valid \\
\hline Citra & 0,558108 & 0,5 & Valid \\
\hline Loyalitas & 0,661373 & 0,5 & Valid \\
\hline
\end{tabular}

Berdasarkan hasil diatas dapat dijelaskan bahwa dari hasil ketjuh variabel memiliki nilai AVE diatas 0,5 sehingga dapat dikatakan data memiliki discriminant validity yang baik. Kriteria reliabilitas juga dapat dilihat dari nilai Cronbach's Alpha suatu variabel dari masing-masing variabel. Cronbach's Alpha, item yang mengukurkonsistensi internal dari item pembentuk variabel. Nilai batas untuk tingkat reliabilitas diatas 0,7 . Berikut hasil uji reliabilitas sebagai berikut : 
Tabel 6

Hasil Uji Discriminant Validity - NilaiCronbach's Alpha

\begin{tabular}{|l|c|c|c|}
\hline \multicolumn{1}{|c|}{ Variabel } & $\begin{array}{c}\text { Cronbach's } \\
\text { Alpha }\end{array}$ & Kriteria & Keterangan \\
\hline Kepercayaan & 0,832514 & 0,7 & Reliabel \\
\hline Switching Barriers & 0,819860 & 0,7 & Reliabel \\
\hline Citra & 0,885378 & 0,7 & Reliabel \\
\hline Loyalitas & 0,823425 & 0,7 & Reliabel \\
\hline
\end{tabular}

Hasil analisis uji reliabilitas menginformasikan bahwa seluruh variabel memenuhi Cronbach's Alpha diatas 0,7 sudah memenuhi kriteria reliabel dan layak untuk digunakan dalam penelitian selanjutnya. Berdasarkan hasil evaluasi secara keseluruhan, baik convergent validity, discriminant validity, dan uji reliabilitas dengan Cronbach's Alpha yang telah dipaparkan di atas, dapat disimpulkan bahwa item pernyataan sebagai pengukur variabel merupakan pengukur yang valid dan reliabel.

\section{a. PengujianR-Square}

Berikut besarnya nilai R-Square pada hubungan antara konstruk penelitian ditunjukkan dalam tabel berikut.

Tabel 7. Hasil pengujian R-Square

\begin{tabular}{lc}
\hline \multicolumn{1}{c}{ Konstruk } & R Square \\
\hline Kepercayaan dan Switching barriers & 0,492374 \\
Kepercayaan dan Citra & 0,547385 \\
Loyalitas nasabah & 0,440687 \\
\hline
\end{tabular}

Berdasarkan Tabel 7 dapat dijelaskan pengaruh dari variabel eksogen terhadap variabel endogen, diperoleh nilai R Square pada konstruk switching barriers sebesar 0,492374 yang berarti kepercayaan mampu menjelaskan pengaruhnya pada switching barriers sebesar 49,23\%. Selanjutnya diperoleh nilai R Square pada konstruk citra sebesar 0,547385 yang berarti kepercayaan mampu menjelaskan pengaruhnya pada citrasebesar 54,73\%. Dan kemudian diperoleh nilai $\mathrm{R}$ Square pada konstruk loyalitas nasabah sebesar 0,440687 yang berarti kepercayaan, switching barriers, dan citra mampu menjelaskan pengaruhnya pada loyalitas nasabah sebesar $44,06 \%$.

\section{b. Pengujian Model Struktural (Inner Model)}

Pengujian ini dilihat dari hasil inner model atau model struktural dilakukan untuk melihat hubungan antara variabel, nilai signifikansi dan $\mathrm{R}$ square dari model penelitian. Hasil analisis model struktural sebelum moderasi dapat dilihat dari gambar model sebagai berikut : 


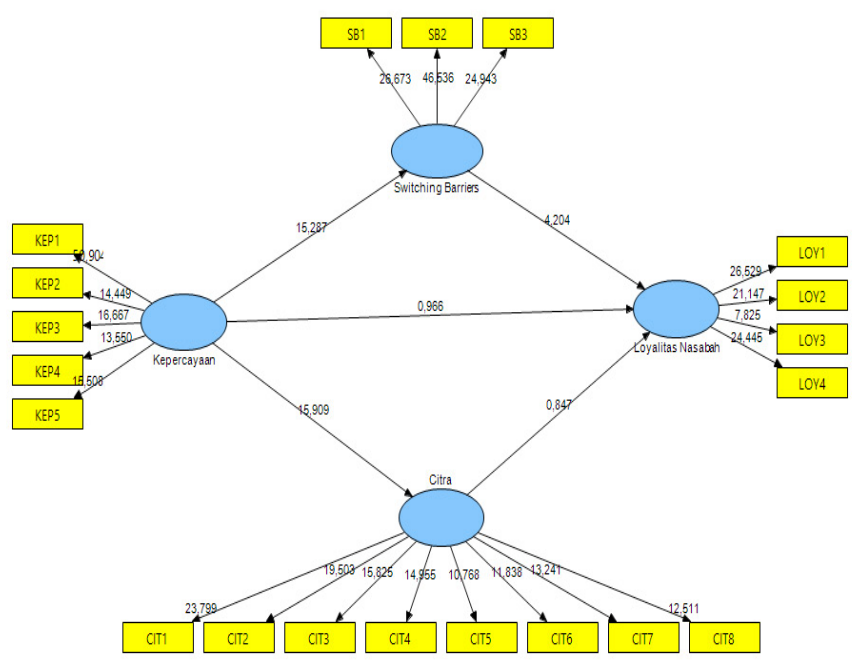

Gambar 3: Output Bootstrapping

Berdasarkan gambar di atas dapat pengujian analisis model struktural pada dijelaskan hubungan antara konstruk penelitian pengaruh kepercayaan, switching barriers dan atau pengaruh dari variabel eksogen terhadap citra bank terhadap loyalitas nasabah Bank variabel endogen. Berikut rangkuman hasil Papua Cabang Yogyakarta.

Tabel 8

Hubungan Variabel Penelitian

\begin{tabular}{lcc}
\hline \multicolumn{1}{c}{ Hubungan Variabel Penelitian } & Original Sample $(\mathrm{O})$ & T Statistics $(|\mathrm{O} / \mathrm{STERR}|)$ \\
\hline Kepercayaan ->Switching barriers & 0,701694 & 15,287310 \\
Kepercayaan ->Citra & 0,739854 & 15,909366 \\
Kepercayaan ->Loyalitas nasabah & 0,151372 & 0,965705 \\
Switching barriers -> Loyalitas nasabah & 0,484438 & 4,204118 \\
Citra ->Loyalitas nasabah & 0,086494 & 0,847145 \\
\hline
\end{tabular}

\section{Hasil PengujianHipotesis}

Untuk melakukan pengujian ini digunakan uji t, dengan membandingkan nilai $t_{\text {hitung }}$ dengan nilai $t_{\text {tabel }}$. Jika diperoleh besarnya nilai $t_{\text {hitung }} \geq t_{\text {tabel }}$ maka hipotesis diterima dan jika nilai $\mathrm{t}_{\text {hitung }}<\mathrm{t}_{\text {tabel }}$ maka hipotesis ditolak.

a. Pengujian pengaruh kepercayaan terhadap switching barriers

Berdasarkan hasil uji t diperoleh nilai original sample estimate sebesar 0,701694 dan memiliki nilait $_{\text {hitung }}$ sebesar 15,287310. Berdasarkan pengujian satu sisi diperoleh nilai $t_{\text {tabel }}$ dengan $\mathrm{n}=84$, maka diperoleh df $(n-1=84-1=83)=1,6634$, sehingga diperoleh nilai $\mathrm{t}_{\text {hitung }}>$ dari nilai $\mathrm{t}_{\text {tabel }}$ atau $(15,287310>1,6634)$. Hal ini dapat diartikan bahwa kepercayaanmemiliki pengaruh signifikan terhadapswitching barriers, sehingga hipotesis pertama yang menyatakan kepercayaan berpengaruh positif signifikan terhadap switching barriers terbukti.

b. Pengujian pengaruh kepercayaan terhadap citra

Berdasarkan hasil uji $\mathrm{t}$ diperoleh nilai original sample estimate sebesar 0,739854 dan memiliki nilai $\mathrm{t}_{\text {hitung }}$ sebesar 15,909366. Berdasarkan pengujian satu sisi diperoleh nilai $\mathrm{t}_{\text {tabel }}$ dengan $\mathrm{n}$ $=84$, maka diperoleh $\mathrm{df}(\mathrm{n}-1=84-1=$ $83)=1,6634$, sehingga diperoleh nilai $\mathrm{t}_{\text {hitung }}>$ dari nilai $\mathrm{t}_{\text {tabel }}$ atau $(15,909366$ $>1,6634)$. Hal ini dapat diartikan bahwa kepercayaanmemiliki pengaruh signifikan terhadapcitra, sehingga hipotesis kedua yang menyatakan kepercayaan 
berpengaruh positif signifikan terhadap citra bankterbukti.

c. Pengujian pengaruh kepercayaan terhadap loyalitas nasabah

Berdasarkan hasil uji $\mathrm{t}$ diperoleh nilai original sample estimate sebesar 0,151372 dan memiliki nilai $\mathrm{t}_{\text {hitung }}$ sebesar 0,965705 . Berdasarkan pengujian satu sisi diperoleh nilai $\mathrm{t}_{\text {tabel }}$ dengan $\mathrm{n}=84$, maka diperoleh df $(n-1=84-1=83)=1,6634$, sehingga diperoleh nilai $\mathrm{t}_{\text {hitung }}<$ dari nilai $\mathrm{t}_{\text {tabel }}$ atau $(0,965705<1,6634)$. Hal ini dapat diartikan bahwa kepercayaantidak berpengaruh terhadaployalitas nasabah, sehingga hipotesis ketiga yang menyatakan kepercayaan berpengaruh positif signifikan terhadap loyalitas nasabah tidak terbukti.

d. Pengujian pengaruh switching barriers terhadap loyalitas nasabah

Berdasarkan hasil uji $\mathrm{t}$ diperoleh nilai original sample estimate sebesar 0,484438 dan memiliki nilai $t_{\text {hitung }}$ sebesar 4,204118 . Berdasarkan pengujian satu sisi diperoleh nilai $t_{\text {tabel }}$ dengan $\mathrm{n}=84$, maka diperoleh df $(n-1=84-1=83)=1,6634$, sehingga diperoleh nilai $t_{\text {hitung }}>$ dari nilai $\mathrm{t}_{\text {tabel }}$ atau $(4,204118>1,6634)$. Hal ini dapat diartikan bahwa switching barriers memiliki pengaruh signifikan terhadap loyalitas nasabah, sehingga hipotesis keempat yang menyatakan switching barriers berpengaruh positif signifikan terhadap loyalitas nasabah terbukti.

e. Pengujian pengaruh citra terhadap loyalitas nasabah

Berdasarkan hasil uji $\mathrm{t}$ pada diperoleh nilai original sample estimate sebesar 0,086494dan memiliki nilai $t_{\text {hitung }}$ sebesar 0,847145 . Berdasarkan pengujian satu sisi diperoleh nilai $\mathrm{t}_{\text {tabel }}$ dengan $\mathrm{n}=84$, maka diperoleh $\mathrm{df}(\mathrm{n}-1=84-1=83)=$ 1,6634 , sehingga diperoleh nilai $t_{\text {hitung }}<$ dari nilai $t_{\text {tabel }}$ atau $(0,847145<1,6634)$. Hal ini dapat diartikan bahwa citratidak berpengaruh signifikan terhadaployalitas nasabah, sehingga hipotesis kelima yang menyatakan citra bank berpengaruh positif signifikan terhadap loyalitas nasabah tidak terbukti.

\section{Pembahasan}

a. Pengaruh kepercayaan terhadap switching barriers

Berdasarkan hasil analisis data menunjukkan bahwa kepercayaan berpengaruh signifikan dan positif terhadap switching barriers, sehingga makin tingginya kepercayaan nasabah pada Bank Papua akan meningkatkan switching barriers pada nasabah. Hal ini menjelaskan bahwa semakin tingginya kepercayaan dari para nasabah akan Bank Papua menjadikan mereka merasa sulit untuk berpindah ke bank lain, karena untuk berpindah pada bank lain para nasabah belum memiliki kepercayaan pada bank lain tersebut apakah akan lebih baik atau bahkan malah lebih jelek dari bank yang mereka gunakan saat ini.

\section{b. Pengaruh kepercayaan terhadap citra}

Pengujian ini menunjukkan bahwa kepercayaan terbukti memberikan pengaruh yang signifikan dan positif terhadap citra, sehingga makin tingginya kepercayaan nasabah pada Bank Papua akan membuat citra dari Bank Papua juga makin meningkat. Tingginya kepecayaan dari nasabah pada Bank Papua ternyata akan menjadikan citra bank tersebut dimata mereka juga makin baik. Dengan kepercayaan yang tinggi mereka mempersepsikan Bank Papua sebagai bank yang memiliki citra baik dibandingkan dengan bank-bank lain yang mungkin belum pernah mereka coba sebelumnya.

\section{c. Pengaruh kepercayaan terhadap loyalitas nasabah}

Hasil penelitian ini menunjukkan bahwa kepercayaan tidak terbukti memberikan pengaruh terhadap loyalitas nasabah, sehingga perubahan kepercayaan yang terjadi pada nasabah belum menyebabkan perubahan pada loyalitasnya pada Bank Papua. Dengan demikian kepercayaan yang tinggi belum menjadi jaminan bahwa loyalitas nasabah juga makin tinggi, ini menunjukkan bahwa faktor 
kepercayaan bukan merupakan prediksi kuat terhadap loyalitas nasabah. Berarti terdapat faktor-faktor lain yang menyebabkan seseorang nasabah loyal pada jasa bank tersebut, seperti faktor kualitas dan kepuasan yang diterima oleh seseorang nasabah. Tidak adanya pengaruh ini dikarenakan kepercayaan yang terjadi pada nasabah jika tidak diikuti dengan pelayanan yang baik dari bank diyakini belum menjadikan nasabah tersebut loyal pada Bank Papua. Hal inilah yang menjadikan kepercayaan tidak memberikan pengaruh yang signifikan terhadap loyalitas nasabah pada Bank Papua Cabang Yogyakarta. Dan hasil penelitian ini belum sependapat dengan Morgan dan Hunt yang mengungkapkan bahwa perilaku keterhubungan yang terjadi antara perusahaan dan konsumen banyak ditentukan oleh kepercayaan, kepercayaan akan mempunyai hubungan yang positif dengan niat ulang maupun loyalitas. Dan juga tidak sejalan dengan dengan hasil penelitian Majid (2013) yang menyimpulkan bahwa kepercayaan memberikan pengaruh langsung terhdap loyalitas nasabah. Subroto dan Anita (2014) menunjukkan bahwa kepercayaan pada perusahaan berpengaruh langsung terhadap loyalitas konsumen. Riskayanti dan Sonang (2016) yang menemukan kepercayaan berpengaruh signifikan dan positif terhadap loyalitas.

\section{d. Pengaruh switching barriers terhadap loyalitas nasabah}

Berdasarkan hasil analisis data menunjukkan bahwa switching barriers berpengaruh positif dan signifikan terhadap loyalitas nasabah, sehingga makin tingginya penghambat untuk berpindah akan menyebabkan makin tingginya loyalitas nasabah pada Bank Papua. Hal ini menjelaskan bahwa tingginya hambatan seseorang untuk berpindah pada jasa bank lain memberikan kontribusi signifikan dalam mempengaruhi loyalitas seorang nasabah untuk tidak berpindah ke bank lain. Apabila switching barriers pada perusahaan tinggi, mereka dapat terus mempertahankan pelanggan meski tingkat kepuasan pelanggan rendah (Rahadian, 2006). Hal ini diperkuat dengan hasil penelitian Subroto dan Anita (2014) yang menemukan bahwa switching barriers berpengaruh langsung terhadap loyalitas konsumen. Penelitian Ishak dan Luthfi (2011) menunjukkan bahwa loyalitas konsumen terhadap layanan tertentu tidak hanya ditentukan oleh kualitas layanan saja tetapi juga ditentukan oleh kemungkinan adanya hambatan untuk berpindah ke layanan lain (switching barriers).

\section{e. Pengaruh citra terhadap loyalitas nasabah}

Berdasarkan hasil analisis data menunjukkan bahwa citra tidak terbukti memberikan pengaruh terhadap loyalitas nasabah, sehingga perubahan citra yang terjadi pada nasabah belum menyebabkan perubahan pada loyalitasnya pada Bank Papua. Dengan demikian, citra dari sebuah layanan belum menjamin keberadaan seseorang untuk tetap loyal pada layanan tersebut, mereka masih dapat berpindah pada jasa layanan lain. Hal ini dapat dikarenakan citra tidak langsung berhubungan dengan layanan yang diterima nasabah bahkan terlebih lagi pada nasabah baru yang masih sedikit mendapatkan layanan secara keseluruhan. Nasabah ini belum sepenuhnya mencurahkan loyalitasnya pada bank tersebut, mereka masih mencari dan memilih yang terbaik bagi dirinya. Hal ini belum sependapat dengan (Rosidah, 2011) yang menyatakan reputasi baik bagi perusahaan yang memasarkan produk atau jasa menjadi faktor penting dalam peningkatan loyalitas konsumen. Jika perusahaan memiliki reputasi yang baik, maka konsumen akan menunjukkan sikap menyukai perusahaan tersebut dan loyal terhadap produk dan jasa perusahaan yang bersangkutan. Dan juga belum sejalan dengan penelitian Subroto dan Anita (2014) menyimpulkan bahwa citra perusahaan berpengaruh langsung terhadap loyalitas konsumen. Riskayanti dan Sonang (2016) menyatakan citra perusahaan berpengaruh signifikan dan positif terhadap loyalitas pengguna jasa 
PT Pos Indonesia (Persero) Surabaya. Tingkir (2014) menyebutkan bahwa citra mempengaruhi loyalitas kepada merek Toyota.

\section{f. Pengaruhkepercayaan terhadap loyalitas nasabah yang dimediasi switching barriers}

Besarnya pengaruh langsung kepercayaan terhadap loyalitas nasabah adalah sebesar $15,1 \%$. Hal ini berarti makin tingginya kepercayaan nasabah pada Bank Papua akan menyebabkan tingginya loyalitas nasabah, dengan demikian kepercayaan ini akan membawa nasabah sepenuhnya mengandalkan Bank Papua sebagai jasa perbankan. Jadi dengan kepercayaan memberikan dampak positif terhadap niat ulang maupun loyalitas nasabah. Kepercayaan konsumen mempunyai pengaruh terhadap loyalitas berupa niat ulang melakukan pembelian, dan melakukan intensitas pembelian ulang. Menurut Morgan dan Hunt mengungkapkan bahwa perilaku keterhubungan yang terjadi antara perusahaan dan konsumen banyak ditentukan oleh kepercayaan. Selanjutnya pada penelitian ini menunjukkan besarnya pengaruh tidak langsung kepercayaan terhadap loyalitas nasabah sebesar $34,0 \%$ dan terbukti switching barriers mampu memediasi pengaruhkepercayaan terhadap loyalitas nasabah. Adanya pengaruh tidak langsung ini menunjukkan terdapatnya kontribusi yang signifikan dari switching barriers dalam meningkatkan loyalitas nasabah, sehingga makin tingginya switching barriers akan memberikan dampak yang besar terhadap kesetiaan nasabah pada Bank Papua.

\section{g. Pengaruh kepercayaan terhadap} loyalitas nasabah yang dimediasi citra Pada pengujian ini menunjukkan besarnya pengaruh langsung kepercayaan terhadap loyalitas nasabah adalah sebesar $15,1 \%$. Hal ini berarti makin tingginya kepercayaan nasabah pada Bank Papua akan menyebabkan tingginya loyalitas nasabah, dengan demikian kepercayaan ini akan membawa nasabah sepenuhnya mengandalkan Bank Papua sebagai jasa perbankan. Hal ini sependapat dengan Morgan dan Hunt yang mengungkapkan bahwa perilaku keterhubungan yang terjadi antara perusahaan dan konsumen banyak ditentukan oleh kepercayaan. Selanjutnya pada penelitian ini menunjukkan besarnya pengaruh tidak langsung kepercayaan terhadap loyalitas nasabah sebesar $6,4 \%$, namun tidak terbukti bahwacitra mampu memediasi pengaruhkepercayaan terhadap loyalitas nasabah. Dengan demikian, citra bank belum mampu memberikan kontribusi yang signifikan dalam meningkatkan loyalitas nasabah, sehingga kondisi citra bank saat ini belum memberikan dampak yang besar terhadap kesetiaan nasabah pada Bank Papua. Tidak terbuktinya citra memediasi pengaruhkepercayaan terhadap loyalitas nasabah dapat disebabkan persepsi yang diperoleh nasabah lebih banyak berasal dari orang lain yang mengatakan bahwa citra dari Bank Papua baik, namun disisi lain nasabah tersebut belum mendapatkan pengalaman langsung atau yang sebenarnya akan keberadaan dari Bank Papua dalam memberikan pelayanannya. Untuk itu, citra atau persepsi yang diperoleh belum mampu memperkuat pengaruh kepercayaan nasabah terhadap loyalitasnya pada Bank Papua.

\section{KESIMPULAN}

Kesimpulan dari hasil penelitian ini adalah sebagai berikut:

1. Kepercayaan terbukti memberikan pengaruh yang signifikan dan positif terhadapswitching barriers, sehingga makin tingginya kepercayaan nasabah pada Bank Papua akan meningkatkan switching barriers pada nasabah.

2. Kepercayaan terbukti memberikan pengaruh yang signifikan dan positif terhadap citra, sehingga makin tingginya kepercayaan nasabah pada Bank Papua akan membuat citra dari Bank Papua juga makin meningkat.

3. Kepercayaan tidak terbukti memberikan pengaruh terhadap loyalitas nasabah, sehingga perubahan kepercayaan yang 
terjadi pada nasabah belum menyebabkan perubahan pada loyalitasnya pada Bank Papua.

4. Switching barriers terbukti memberikan pengaruh yang signifikan dan positif terhadap loyalitas nasabah, sehingga makin tingginya penghambat untuk berpindah akan menyebabkan makin tingginya loyalitas nasabah pada Bank Papua.

5. Citratidak terbukti memberikan pengaruh yang signifikan dan positif terhadap loyalitas nasabah, sehingga perubahan citra yang terjadi pada nasabah belum menyebabkan perubahan pada loyalitasnya pada Bank Papua.

6. Switching barriers terbukti mampu memediasi pengaruhkepercayaan terhadap loyalitas nasabahBank Papua Cabang Yogyakarta.

7. Citra bank terbukti tidak mampu memediasi pengaruhkepercayaan terhadap loyalitas nasabah

\section{SARAN}

Saran yang dapat diberikan dari penelitian ini adalah sebagai berikut, pihak manajemen bank harus menjaga kepercayaan nasabah yang sudah baik, dengan demikian, akan mengurangi keinginan nasabah untuk berpindah atau mencari bank lain dalam memenuhi kebutuhannya. Pegawai bank sebaiknya selalu menjalin hubungan baik dengan semua nasabah, dengan terjalinnya hubungan baik ini diharapkan akan menjadikan nasabah tidak ingin berpindah pada bank lain. Pihak bank diharapkan dapat meningkatkan pelayanan kepada nasabah agar tetap loyal pada Bank Papua, hal ini antara lain dapat dilakukan dengan menepati janji yang dijanjikan kepada setiap nasabah, dan menjamin bahwa setiap transaksi yang dilakukan di Bank Papua aman, lancar dan cepat.

\section{DAFTAR PUSTAKA}

Berry, L . 1995. Relationship Marketing of Services - Growing Interest, Emerging Perspectives . Journal of the Academy of Marketing Science $23: 236-245$.

Berry, L . and Parasuraman , A. 1991. Marketing Service - Competing through Quality . New York: The Free Press

Ditcher, E. 1985. What's in an IMAGE. Journal of Consumer marketing, 2: 1. 75-81.

Fredericks, Joan O. and Salter II, James M. 1995. Beyond Customer Satisfaction. Management Review, 5. (29-32).

Gremler, Dwayne D. and Brown, Stephen W. 1997. Service Loyalty: Its nature, Importance, and Implications. Advancing Service Quality: A Global Perspective, Edvardsson et al., (eds) Quiz 5, Conference Processing, University of Karlstad, Sweden, (171-181).

Gronross, Christian. 1983. Strategic Management and Marketing in the Service Sector. Cambridge, Massachusetts.

Hennig-Thurau, T., Gwinner, K.P., Gremler, D.D., 2002. Understanding Relationship Marketing Outcomes: An Integration of Relational Benefits And Relationship Quality. Journal of Service Research 4 (February), 230-247.

Ishak, A., dan Luthfi, Z., 2011, Pengaruh Kepuasan Dan Kepercayaan Konsumen Terhadap Loyalitas: Studi Tentang Peran Mediasi Switching Costs, Jurnal Siasat Bisnis, Vol. 15. No. 1.

Jones Chistine and Paul Val, 1993. Accomodation Management: a system approach. BT Batsford Limited, London.

Kandampully, Jay. 1998. Service Quality to Service Loyalty: A Relationship Which Goes 
Beyond Customer Services. Journal of Total Quality Management, 9 (6).

Kirwin, Paul. 1992. Increasing Sales and Profits Through Gues Satisfaction. Cornell H. R. A. Quarterly, 33. (38-39).

Majid, Rahmat, 2013,Customer Trust as Relationship Mediation Between Customer Satisfaction and Loyalty at Bank Rakyat Indonesia (BRI) Southeast Sulawesi, The International Journal Of Engineering And Science (IJES), Volume2, Issue 5.

Morgan, R. dan Hunt, S. 1994, The Commitment-Trust Theory of Relationship Marketing. Journal of Marketing, 58, July, 20-38.

Normann, R. 1991. Service Management: Strategy and Leadership in Service Business. John Wiley and Sons.

Rahadian, S.S., 2006, Analisis Pengaruh Loyalitas Pelanggan dan Perilaku Mencari Variasi terhadap Perpindahan Merek, Tesis, Semarang: Program Studi Magister Universitas Diponegoro Semarang

Riskayanti N dan Sonang S., 2016, Pengaruh Citra Perusahan, Kepercayaan, dan Harga Terhadap Loyalitas Pengguna Jasa, Jurnal Ilmu dan Riset Manajemen : Volume 5, Nomor 2, ISSN : 2461-0593

Roberts, J. 1993. Marketing for the Hospitality Industry. Hodder \& Stoughton, Auckland.

Rosidah, Chikmiatur, 2011, The Influence of Corporate Reputation and Trust to Consumers Loyalty of ATM Users After Cybercrime Issues (Study at BCA Consumers in Surabaya), JurnalBusiness and Economics, 21 Mei 2011

Setiawan, M.B., dan Ukudi., 2011, Pengaruh Kualitas Layanan, Kepercayaan dan Komitmen terhadap Loyalitas Nasabah, Jurnal Bisnis dan Ekonomi (JBE), Vol. 14, No.2, September 2007

Sobol, M. G., Farrelly, G. E.; Taper, J. S. 1992. Shaping the orporate Image: An Analytical Guide for Executive Decision Makers. Quorum Books, New York.

Subroto B dan Anita R, 2014, Research on Impacts of Customer's Satisfaction, Trust, Switching Barriers, and Corporate Image towards Customer's Loyalty (Case Study: Telkom Flexi),International Journal of Science and Technology, Volume 3 No. 11.

Sugandini, D. 2003. Anteseden Loyalitas Konsumen pada Industry Perhotelan (Studi Pada Hotel Berbintang di Daerah Istimewa Yogyakarta). Wahana, Vol. 6 (2), pp. 181-200.

Sugandini D., Rahatmawati, I and Arundati R, (2018), "Environmental Attitude on the Adoption Decision Mangrove Conservation: An Empirical Study on Communities in Special Region of Yogyakarta, Indonesia", Review of Integrative Business and Economics Research, Vol. 7(s1), 266-275.

Sugandini, D., Rahatmawati, I and Istanto, Y, (2017), “Adoption of Natural Dyes for Batik Artisans in Yogyakarta, Indonesia", Review of Integrative Business and Economics Research, 6(1), 349-359.

Sugandini, D., Wendry, B dan Muafi. 2017. Influence of Quality Relationship and Satisfaction on Loyalty: Study on Supplier in Indonesia. Journal of Business \& Retail Management Research. Vol-11, Issue 4, October 2017. Pages:46-51.

Christin, S., Sugandini, D. 2018. Perceived Value, eWord-of-Mouth, Traditional Word-ofMouth, and Perceived Quality to Destination Image of Vacation Tourists. Review 
of Integrative Business and Economics Research, Vol. 7(s1), 312-321. Tingkir CF, 2014, Pengaruh Identitas Merek Terhadap Loyalitas Merek Melalui Citra Merek Dan Kepercayaan Merek Toyota, Jurnal Manajemen Pemasaran, Vol. 8, No. 2, ISSN 1907-235X

Zeithaml, V. A. \& Bitner, M. J. 1996. Services Marketing. McGraw-Hill International Editions. 